\title{
The Development of Education Character Policy and Programs in Information Society of Kampung Cyber Yogyakarta
}

\author{
Muhammad Amirrudin', Harun², Muhammad Yasid³, Surur Roiqoh, Fatkhul Sani \\ Rohana $^{5}$ \\ 1,2Universitas Negeri Yogyakarta, Indonesia \\ ${ }^{5}$ Universitas Gadjah Mada, Indonesia \\ 3,4Universitas Islam Negeri Sunan Kalijaga, Indonesia
}

muhammadamirrudin.2019@student.uny.ac.id

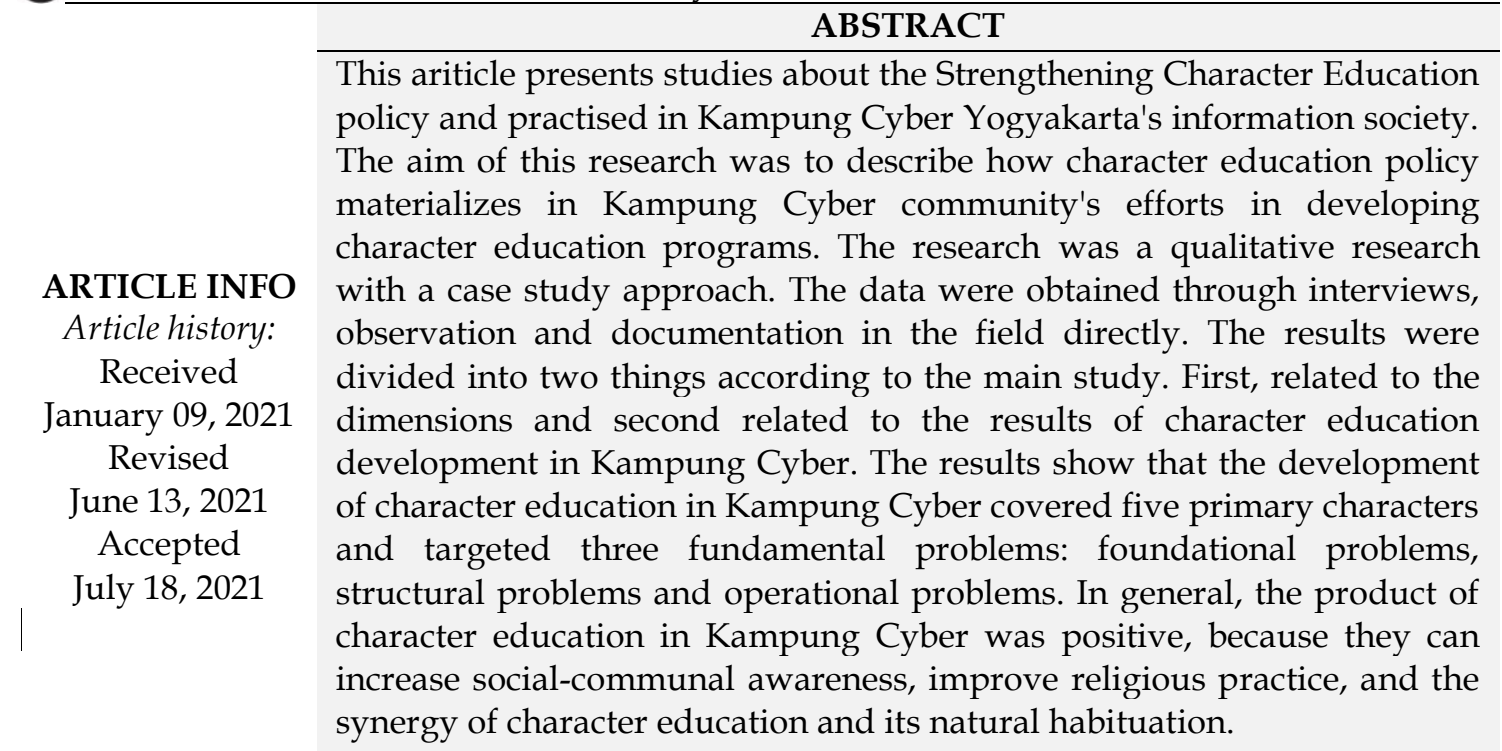

Keywords: Education Character Policy, Strengthening Education Character, Education Character

How to cite Amirrudin, et al., (2021). The Development of Character Education Programs in Information Society of Kampung Cyber Yogyakarta. Jurnal Iqra' : Kajian Ilmu Pendidikan, 6(2). 71-82.

https:// doi.org/10.25217/ji.v6i2.1190.1326

Journal Homepage http://journal.iaimnumetrolampung.ac.id/index.php/ji/

This is an open access article under the CC BY SA license

https://creativecommons.org/licenses/by-sa/4.0/

\section{INTRODUCTION}

Character education is the top priority of Indonesian education. As stated in Law Number 20 Year, 2003(Noor, 2018), education aimed to create good citizen with the best quality balance between their excellent character, skills and knowledge. The Indonesian government often tries to develop character education practices by creating an educational policy environment(Yama \& General, 2015) or managing training for educators(Rachman et al., 2017) to get the best shape. Therefore, character education seems to get serious attention within the framework of the Indonesian education system.

Lickona (1999) interpret that character education has three main goals: good people, good school and a good society. Therefore, school, society and the people themselves are three main characteristics linked with the success of character 
education. So, It should carry out based on grounded, holistic communities values (Fajrussalam et al., 2020) and the family. Unfortunately, character education is typically viewed as the only responsibility of schools as a formal institution despite involving families and communities. It is worrying because most of the formal educational process only introduce students to the standardized concepts with no involvement in social process and practices(Irwan et al., 2019), that will give them experience and opportunities to adopt the character values.

Indonesian government efforts to manage character education do not involve the community formally until the Strengthening Character Education (Penguatan Pendidikan Karakter, mostly called PPK) statue declared back in 2017. The formal involvement of educational stakeholders other than schools in strengthening character education highly emphasized in the Presidential Decree (Perpres no. 87 Tahun 2017, 2017). The government realizes it must carry out character education holistically by involving the educational environment in which students exist.

Strengthening character education (PPK) program aims 1) to build and equip the student with the spirit of Pancasila and good character education in order to face the dynamics of change in the future; and 2) to develop a national education platform that places character education as the main soul in the delivery of education for students with the support of public involvement(Permendikbud RI No 20 Tahun 2018, 2018). Five main character values are interrelated to form a value network that needs to develop as a priority for the PPK program. Religious, nationalism, self-reliance, mutual cooperation and integrity are the five main values of the national character (Effendy, 2017). These five main values of the characters are not standing or developing independently but interacting with each other, developing dynamically and forming personal wholeness.

The education unit that got a mandate to take the responsibility is in formal, informal and non-formal education units. Society, as an educational stakeholder, does not have a specific duty to implement character education. Schools have supporting conditions such as the availability of school institutions, teaching staff, and financial incentives that ensure this program runs. It shows very well that this program has been running smoothly, sustainably, and quite massively(Rachman et al., 2017), especially in school as formal education representation.

However, inversely, the implementation of community-based PPK programs tends to faller, far from being massive and visible. Due to the lack of supporting conditions such as the availability of educational institutions, teaching staff, and financial incentives that ensure this program runs, the absence of derivative regulations, and the lack of initiative from community leaders or religious figures. In comparison, Community leaders and religious figures have pivotal roles and strategic positions in society. For Umami (2018), these roles and positions are spiritual, moral, and ethical foundations in daily life. It also confirmed by Porawouw(2016) and Suhendi(2013) that their roles are related to building social prosperity and very strategic to strengthening building participation.

A different story occurred in society of the Kampung Cyber Yogyakarta, where on the roles and initiatives community leaders and religious figures succeeded in implementing and developing Character Education programs community-based. Meanwhile, many modern Indonesian society entities at this time, in this case, Kampung Cyber, have independently implemented character education in the community long ago. 
Dozen of studies have giving attention on PPK program school-based, whether its focus on the subject(Towaf, 2014), the curricula(Haryati, 2013), student (Dianti, 2014), teacher(Agung, 2017; Rachman et al., 2017), extracurricular program(Dahliyana, 2017), or through environmental issue's program(Purwanti, 2017). The above research, as a whole, focuses its study on educational units in formal schools. But no previous work was found about implementation of PPK program community-based in Yogyakarta.

This artilce contributed to a new dimension to the field of the implementation and development of character education that remained sync with the national program of Strengthening Character Education (PPK). From this background study, its research tries to answer, First, how the policy for Strengthening Character Education (PPK) adapted in Kampung Cyber. Second, how was the implementation of the adaptation policy in the community and third, the results of character education development in Kampung Cyber. A study is needed to find out the extent of the implementation, the development and also the synchronization of this national program with the community-based PPK program.

\section{METHODS}

The research paradigm used is a qualitative research paradigm with a case study approach. Case studies use to develop an in-depth description and analysis of a case Creswell \& Poth(2018). Data were obtained through interviews, observation and documentation in the field directly. In this research, the development of character education that will be studied is the case in Kampung Cyber Yogyakarta as representing the information society. Snowball method used to generate the sample, starting from Kampung Cyber's chief as the leading figure and end up to eight (8) others key figure of Kampung Cyber.

Data analyzed through Miles and Hubberman qualitative data analysis models. According to Creswell, (2014); Miles \& Hubberman(1994) analysis consists of three streams of activity that coincide, namely: data reduction, data presentation, drawing conclusions/verification. In detail, data were reduced into plain form, and then they were grouped based on similar themes. After data were grouped, the next step was to find interrelations between them to understand the pattern comprehensively. The results then used to draw a conclusion of how education character program was carried out in Kampung Cyber Yogyakarta. The data analysis results also discuss how the synchronization of character education programs implemented in Cyber Village with national policy of Strengthening Character Education (PPK). And also to derive alternative guidance of how education character in society was implemented.

\section{RESULT AND DISCUSSION}

The data collection results regarding the policy of character education development in Kampung Cyber started from a statement of the Chief of Kampung Cyber. He said that,

"The development of social, educational and religious activities takes into account with the different backgrounds of the Kampung Cyber community."

The Kampung Cyber secretary and an activist for women and children stated that it should not be tendentious only to target the majority of certain religions or specific work backgrounds in educating the public. The character values conveyed in a pluralistic society such as the Kampung Cyber community must be general so that all parties and backgrounds can accept them. 
The Development of Education Character Policy and Programs in Information Society of Kampung Cyber Yogyakarta

Heterogeneity of Kampung Cyber people shows in the document of villager website http:/ / siwargapatehan.id/ that there are three groups of religious adherents, namely Islam (57.32\%), Catholics (34.39\%) and Christians $(8.28 \%)$. However, in terms of occupation, the data showed more varied and divided.

Figure. 1 Kampung Cyber's resident by occupation

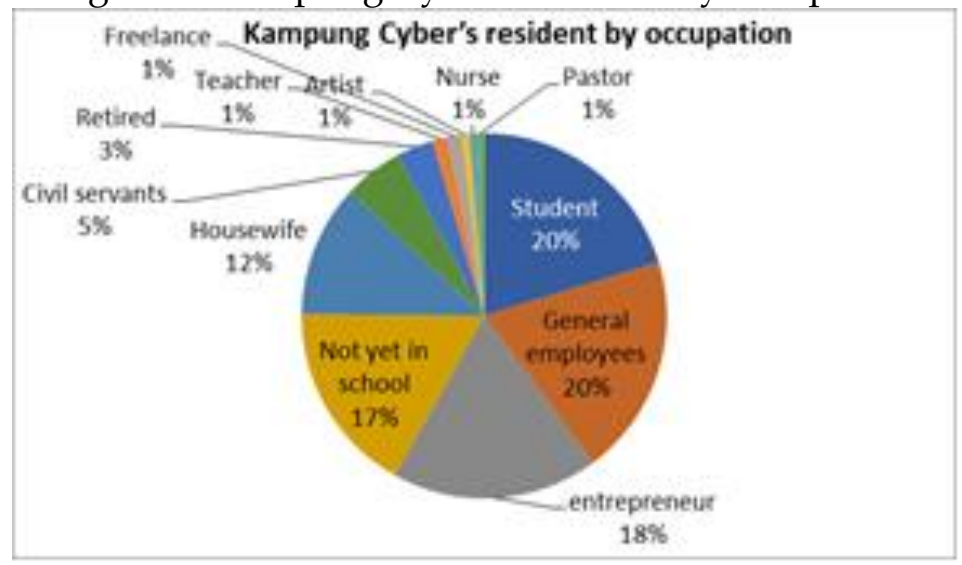

All the diversity has become the motor drive for flexible education development policy. According to the Chief of Kampung Cyber, it has become a habit and norm for residents to help each other succeed in each other's religious activities. It displayed in Picture 1, which shows the Christmas celebration in Kampung Cyber prepared and celebrated with other religious beliefs.

Picture 1. Interreligious celebration during Christmas

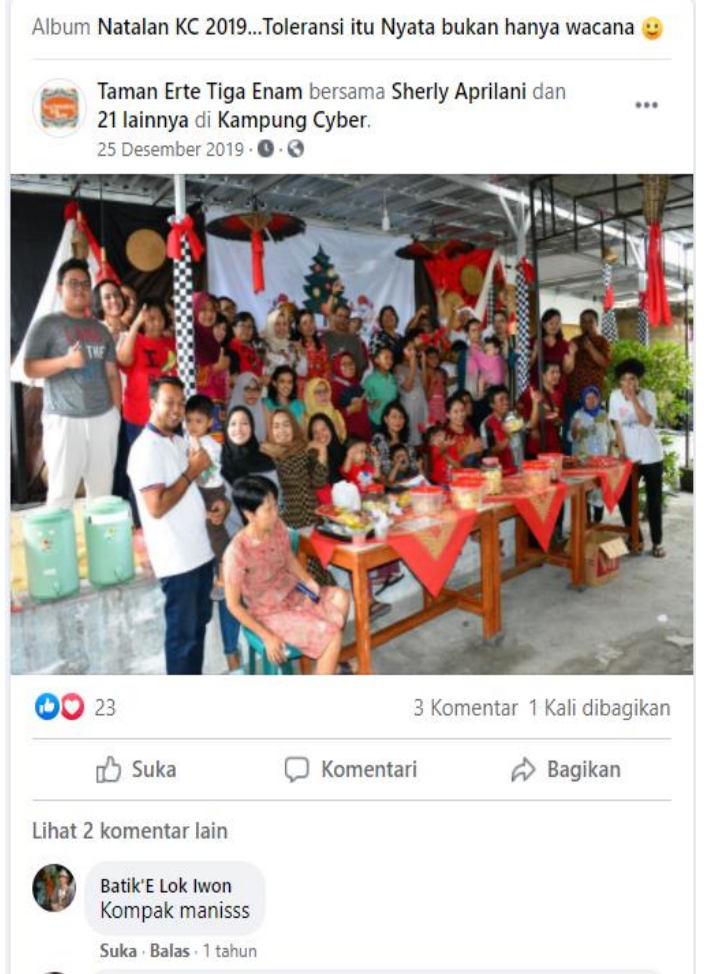

(Source: Facebook group Kampung Cyber, 2019) 
Based on all of the fact, community leaders and religious figures in Kampung Cyber modified the character education policy to be more flexible. Therefore, policies related to character education in Kampung Cyber are prepared according to its citizens' background and characteristics.

Among the policy points is 1) there is no discrimination or special treatment for certain religious groups, 2) character education materials distributed on social media platforms must be based on general values on the basis of humanity, not only for one religion. Nationally, the policy developed by Kampung Cyber is in accordance with the Regulation of the Minister of Education and Culture of the Republic of Indonesia No. 20 of 2018(Permendikbud RI No 20 Tahun 2018, 2018), which crosses to build and equip the student with the spirit of Pancasila and good character education in order to face the dynamics of change in the future and to develop a national education platform that places character education as the main soul in the delivery of education for students with the support of public involvement.

The development of educational policies in the Kampung Cyber community has implications for the character education model developed. It conforms to the segmentation of age and religious background. Because the majority of Kampung Cyberrs are Muslim, character education development is designed through Islamic religious education programs such as TPA for children under 12 years of age, Qur'an for teens for junior high school students and routine recitation for all ages. The nonMuslim community still gets attention to the mass education program. Mr S, the chief and founding of Kampung Cyber, said that Kampung Cyber had identified itself as a Gemeinschaft community, close-knit, centred on the family and kinship, where life lived in a stable community and conflict-free as values are shared (Hyland \& Merrill, 2003), despite the intense use of information technology. In general, the character education program in Kampung Cyber is summarized in Table 1 as below,

Tabel 1 - Character education programs

\begin{tabular}{|c|c|c|}
\hline No & Programs & Target of programs \\
\hline 1. & Qur'an Education for Children (TPA) & Under 12 years old \\
\hline 2. & Qur'an for Teens & Over 12 years old \\
\hline 3. & The Traveling Cleric & General public \\
\hline 4. & Routine Islamic Recitation & General public \\
\hline 5. & Mass Education through Social Media & General public \\
\hline
\end{tabular}

Kampung Cyber managers develop character education through mobile cleric, Quran for teens, and mass education through social media, routine recitation and Quran Education Garden. The results of the comprehensive field study of the character education programs above summarized in Table 2 below.

Table 2-Dimensions of character education development

\begin{tabular}{|l|l|l|}
\hline Development Target Practices & Theme & $\begin{array}{l}\text { Interrelations } \\
\text { among the themes }\end{array}$ \\
\hline $\begin{array}{l}\text { The character material delivered is } \\
\text { inclusive in order to target a } \\
\text { multicultural society. }\end{array}$ & $\begin{array}{l}\text { Foundational } \\
\text { Problem }\end{array}$ & $\begin{array}{l}\text { The development of } \\
\text { character education } \\
\text { in Kampung Cyber } \\
\text { information society } \\
\text { hit the foundational, }\end{array}$ \\
\hline $\begin{array}{l}\text { The character education program is } \\
\text { adjusted for age segmentation. }\end{array}$ & $\begin{array}{l}\text { Structural } \\
\text { Problem }\end{array}$ & \multicolumn{2}{|l}{} \\
\hline
\end{tabular}




\begin{tabular}{|l|l|l|}
\hline $\begin{array}{l}\text { Character education programs were } \\
\text { realized regardless of economic } \\
\text { background over learners. }\end{array}$ & $\begin{array}{l}\text { structural and } \\
\text { operational } \\
\text { domains. }\end{array}$ \\
\cline { 1 - 1 } $\begin{array}{l}\text { Fulfilment of lack of teacher resources } \\
\text { is completed by collaboration with } \\
\text { higher education institutions at the } \\
\text { university level. }\end{array}$ & $\begin{array}{l}\text { Operational } \\
\text { Problems }\end{array}$ & \\
\cline { 1 - 2 } $\begin{array}{l}\text { Attract students with a ball pick-up } \\
\text { system. }\end{array}$ & & \\
\cline { 1 - 2 } $\begin{array}{l}\text { Modification of delivery of material } \\
\text { through social media. }\end{array}$ & & \\
\hline
\end{tabular}

The data presented in Table 2 shows the inclusivity of material designed to promote noble values and life skills. The character values that internalized in the character education programs in Kampung Cyber are universal. According to Mrs Sr as the secretary of Kampung Cyber, "This versatile character material represents the community's social and religious backgrounds. For example, even though in the Islamic routine recitation, held by the Islamic community, the most frequent message conveyed is a brotherhood between fellow human beings."

The development of character education materials, especially in the mass education program, is packaged with light material and inclusive language. Inclusive here means that all people can accept the message regardless of religious background and cultural differences between each kind of groups.

The policy and idea about multicultural values in character education in Kampung Cyber are intended to overcome foundational educational material, so its considered and displayed in the theme column as Foundational problem themes. It is also relevant to the PPK policy in the Presidential Regulation of the Republic of Indonesia Number 87 of 2017(Perpres no. 87 Tahun 2017, 2017) article 3, which states that the aim of the movement to Strengthen Character Education(PPK) is to strengthen the joints of the nation with universal values in Pancasila.

In general, students and society also invited to be active in learning to practice character education directly, such as through mutual cooperation and community service in improving environmental facilities and infrastructure. They initiate development practices in these communities themselves without waiting for orders from the government. This togetherness is rooted in forming harmonious social practices. It is exemplified by helping out for different religious communities, for example, Muslims helping to prepare Christmas celebrations for Christians and vice versa.

The other two themes are displayed as structural problems and operational problems. Structural problems addressed to cover the theme because the character education program adjusted by some structural society background such as age and economic conditions. Ustad/cleric in charge of children's education said,

"The design of moral education adjusts one of them to the age background of the community. Therefore, among the programs provided are based on the age of the community, namely, general recitation for parents, Qur'an for teens for teenagers and Qur'an for children for young children."

In addition to physical character education programs, a character education model utilizes virtual space. In line with what Lewis \& Allan(2005) said, virtual 
learning communities created for various reasons, including cascading new work practices through organizations; to bring people together to share good practice; to provide new approaches to learning or service improvements, and to support learning and training programmes. Ms Sr said that,

"Social media such as Facebook and WhatsApp, apart from helping in disseminating information, we can also use it to educate the public."

Programs deployed periodically by spreading messages of religion, harmony, hard work and the value of community life. Picture 2 shows the practice of character education models for the Kampung Cyber community through the Facebook group social media. In the Facebook group post below, a message shared to all Kampung Cyber residents, implicitly, for keeping the spirit and working hand in hand to work together among community members.

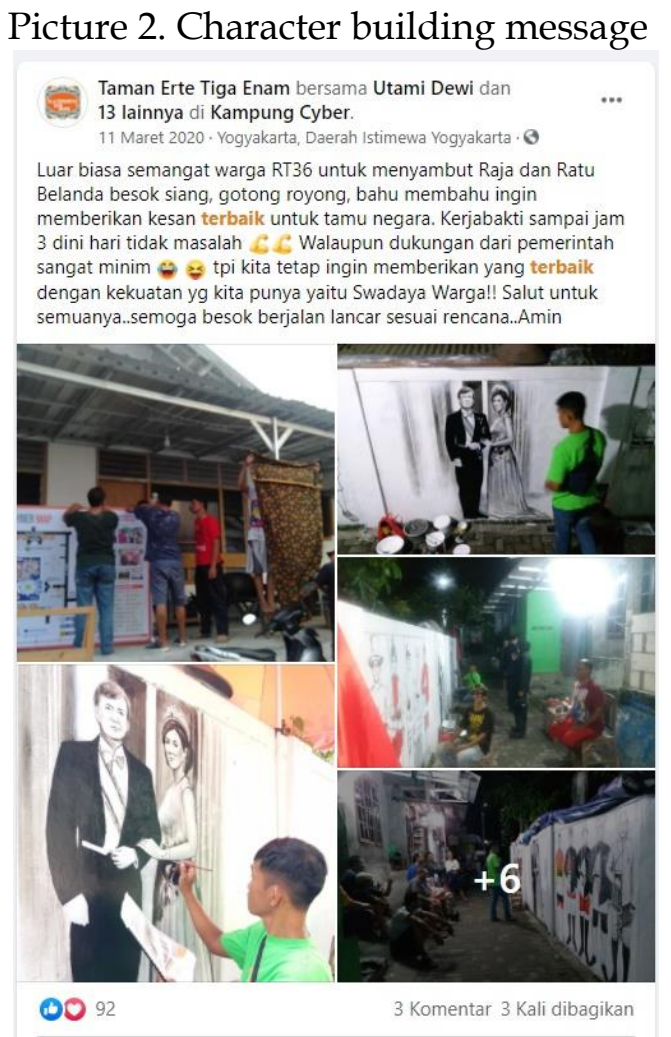

(Source: Facebook group Kampung Cyber, 2020)

Furthermore, it is displayed as an operational problems theme at the level of solving operational problems such as lack of teacher resources, learning modifications, and student participation. The operational problems theme covered all of the management personnel on individuals' independence and society in general. Character education programs made in Kampung Cyber are different without assistance from the government or educational units. Chief of Kampung Cyber said,

"Kampung Cyber development efforts are mostly initiated independently by the community themselves without a massive assistance from government money."

It is different from the mandate of the Presidential Regulation of the Republic of Indonesia number 87 of 2017(Perpres no. 87 Tahun 2017, 2017) article 1 paragraph 1, which states that Strengthening Character Education is the responsibility of the education unit as a representation of government. The community's position as in the 
Strengthening Character Education movement is explained in the Regulation of the Minister of Education and Culture of the Republic of Indonesia Number 20 of 2018(Permendikbud RI No 20 Tahun 2018, 2018) article 5 paragraph 5, namely just as an organizing partner.

It brings positive consequences for students instead. The character education program developed in Kampung Cyber could directly meet what student needs and social expectation. It avoids what most educational developers in formal schools are afraid that what they develop is not in accordance with what is needed by the community; their fear is of "relevance" (Fischman et al., 2006). According to the students' parents, the design, judging from the study results in the field of character education programs, able to cover people from all social and religious backgrounds.

Parents of Kampung Cyber students, three families with teenagers and children, were interviewed to determine the effectiveness of the character education development program in Kampung Cyber. The character education program in Kampung Cyber emphasizes increasing the quantity and the quality of students' religiosity. The three families interviewed found that the thing they emphasized the most on their children was worship. There are several programs that students can participate in to deepen their religion, including the Qur'an for Teens, Al-Qur'an Education Park, Traveling Islamic Cleric and Routine Islamic Recitation. Based on field observations, the researcher found that these activities could mobilize students to worship together while increasing their religious knowledge. In addition, personal awareness about the consequences of good and bad deeds makes them aware of the value of mutual respect between humans and the value of integrity.

The interview data obtained from Mr Sp with two junior high school-age children explain that, "Educational programs such as the Qur'an for children make it easier for parents to manage the character of their children. My children are more organized and willing to help parents with their housework."

In line with Mr Sp, Mr Sy with one teenage child said that the community environment and educational programs in Kampung Cyber helped shape their children's personalities to be better. Based on observations, children, especially Muslim ones, dare to lead the most beautiful worship together and at the same time lead prayers. It is a matter of pride for Mr Sy.

Besides being able to increase the level of diligent behaviour in worship, educational programs in the Kampung Cyber also teach students to engage with the community properly. DF, son of $\mathrm{Mr} \mathrm{Dj}$, several times can well chat with adults with polite language. The value of respecting elders applies well to Df and, as far as we can see, applies to society in general. According to Mr DJ, his child's behaviour formed apart from education from the family but also directly from the Qur'an program for children and, of course, with the support of other community leaders.

"Here (Kampung Cyber) children are really taught to respect each other, especially older people. This value is held very closely by all Kampung Cyber stakeholders to passed on to the next generation."

Attractive to note how was this collaboration had so successfully developed even without government assistance. Tremblay's study on Kampung Cyber(2019) revealed a lack of faith in seeking connections with and feared that the government would be too limiting and impinge on their freedom of choice. So it leads to their independent collaboration that could bring such a positive vibe to the implementation of whole programs. As Rozafi(2019) studies, spontaneous activity and direct exemplary could lead to effective results on teaching character. 
In general, the effectiveness and impact of character education programs developed in Kampung Cyber can see in Table 3. The first column shows the findings in the field from the results of observations, interviews and documentation. The result then displayed according to the proximity of the theme and then concluded in the third column. Therefore, the detailed impact of the development of character education in Kampung Cyber can be as follows.

Table 3-Impact of Character Education

\begin{tabular}{|c|c|c|}
\hline Impact of Character Education & Theme & $\begin{array}{l}\text { Interrelations among } \\
\text { themes }\end{array}$ \\
\hline $\begin{array}{l}\text { Learners show diligent behavior in } \\
\text { worship }\end{array}$ & \multirow{3}{*}{$\begin{array}{l}\text { Increase in } \\
\text { religious } \\
\text { practices. }\end{array}$} & \multirow{10}{*}{$\begin{array}{l}\text { The development of } \\
\text { character education in } \\
\text { Kampung Cyber } \\
\text { community is effective } \\
\text { in increasing awareness } \\
\text { of religious practices, } \\
\text { increasing social- } \\
\text { communal awareness } \\
\text { and its synergy between } \\
\text { the concept of character } \\
\text { education and its } \\
\text { natural habituation. }\end{array}$} \\
\hline $\begin{array}{l}\text { Learners show an increase in daily } \\
\text { worship practices }\end{array}$ & & \\
\hline $\begin{array}{l}\text { Personal awareness of the consequences } \\
\text { of good and bad deeds (concept of sin) }\end{array}$ & & \\
\hline $\begin{array}{l}\text { Liveliness of community participation } \\
\text { in the formulation of the Kampung } \\
\text { Cyber programs. }\end{array}$ & \multirow[t]{3}{*}{$\begin{array}{l}\text { Increase social- } \\
\text { communal } \\
\text { awareness. }\end{array}$} & \\
\hline $\begin{array}{l}\text { Increased individual participation in } \\
\text { social activities }\end{array}$ & & \\
\hline $\begin{array}{l}\text { Sense of belonging as part of the } \\
\text { society. }\end{array}$ & & \\
\hline $\begin{array}{l}\text { Improvement of good practice character } \\
\text { education. }\end{array}$ & \multirow{4}{*}{$\begin{array}{l}\text { The synergy of } \\
\text { the concept of } \\
\text { character } \\
\text { education and } \\
\text { its natural } \\
\text { habituation } \\
\text { practices. }\end{array}$} & \\
\hline $\begin{array}{l}\text { Learners interact well with society and } \\
\text { peers. }\end{array}$ & & \\
\hline Learners find role models in society. & & \\
\hline $\begin{array}{l}\text { Learners gain real consequences of their } \\
\text { deed. }\end{array}$ & & \\
\hline
\end{tabular}

The main finding of this research is that the implementation of the Communitybased Character Education Strengthening policy from the Presidential Regulation in 2018 Number 20 and the Minister of Education and Culture Regulation in 2017 Number 87 about Strengthening Character Education(PPK) has been implemented long before the PPK policy itself came out. This study well succeeded in dissecting the modification and implementation of the Strengthening Character Education model, which the Kampung Cyber Community independently initiated. The development of character education in the Kampung Cyber community effectively increases awareness of religious practices, increasing social-communal awareness and its synergy between the concept of character education and its natural habituation. It shows that the development of character education in Kampung Cyber has an effective impact as concluded in Table 3. Kampung Cyber is the exemplification of how character education rooted and independently develop in Indonesia's society. It displays an 
example of how modern society in Indonesia deals with character education. Although the development of character education policy in Indonesia is indivisible from the social and political dynamics and instead it is used as a tool to support the ruler's status quo (Husni, 2020) The school curriculum only forms the ideal type of character, does not stimulate the active involvement of students in the community. However, a society with their own collaboration keeps assisting in developing their educational character programs naturally. The character of religiosity, nationalism, independence, cooperation and integrity are among the character education programs in Kampung Cyber that appropriate with the government goals/programs. These programs are designed with comprehensive attention to society's main problems, including foundational, structural and operational issues.

Several studies have giving attention to PPK program school-based, whether its focus on the subject(Towaf, 2014), the curricula(Haryati, 2013), student (Dianti, 2014), teacher(Agung, 2017; Rachman et al., 2017), extracurricular program(Dahliyana, 2017), based on school culture (Fitri Nur Hayati, Suyatno, tahun), offer strategic ways without forgetting "tri pusat pendidikan" (Soraya, 2020), Contextual Learning Based on Local Wisdom (Ramdani, 2018), education ecosystem (Perdana, 2018), living value education (Komalasari \& Saripudin, 2018) or through environmental issue's program(Purwanti, 2017). Moreover, a few studies have also given attention to community participation in character education development. Some of them are related to Indigenous Education Whatman, S., \& Duncan, P. (2005), the school community's participation Mustiningsih ( 2019), Aan Komariah(2020), Jagad Aditya Dewantara (2020). The above research, as a whole, focuses its study on academic units in formal schools. However, no previous work was found about the implementation of the PPK program community-based in Yogyakarta.

This research contributes to shows an overview of society as an essential actor and object of character education. Therefore, community involvement in the development of student character education is a necessity. Character education is rooted in society and effectively educates students to become fully integrated human beings with real-life is indisputable. It hoped that this research's results could consider the government's future strengthening of character education policies. This research can provide an overview of society as an essential actor and object of character education. Community involvement in the development of student character education is a necessity. The fact that character education is rooted in society and effectively educates students to become fully integrated human beings with real-life is indisputable. It hoped that this research's results could use to consider the government's future strengthening of character education policies. This study has limitations where the case only applies to Kampung Cyber. Generalization cannot be made in general to all Indonesian society, given that the model of society in Indonesia is very varied.

\section{CONCLUSION}

Kampung Cyber character education programs are designed with comprehensive attention to society's main problems, including foundational, structural and operational issues. It is designed to suit the social conditions and background of a multicultural society and integrate character education with the social realities of society. This integrative education system makes it easy for students to receive character material as well as practice it holistically. The character education program in Kampung Cyber in the end able to achieve the character goals of the Strengthening 
Character Education movement launched by the government in the Presidential Regulation of the Republic of Indonesia Number 87 of 2017 and the Regulation of the Minister of Education and Culture of the Republic of Indonesia Number 20 of 2018, namely religiosity, nationalism, independence, mutual cooperation and integrity. It shows that the character education program initiated by the Kampung Cyber Community is effective, and its existence is vital to be recognized by the government as an example and great asset.

\section{ACKNOWLEDGEMENT}

The author would like to say thanks to all participants participating in this project. Much appreciation delivered to whose become moral boost and partnering in this long term project.

\section{AUTHOR CONTRIBUTION STATEMENT}

Muhammad Amirrudin designed the research and collected data in the field. Muhammad Yazid, Fatkhul Sani Rohana, Surur Roiqoh have developed the theoretical formalism, performed the data analytically and performed correction and polished the paper. The last person Harun supervised the project. All of the authors contributed to the final version of the manuscript.

\section{REFERENCES}

Agung, I. (2017). Peran Fasilitator Guru Dalam Penguatan Pendidikan Karakter (Ppk). Perspektif Ilmu Pendidikan, 31(2), 106-119. https:/ / doi.org/10.21009/ pip.312.6

Creswell, J. W. (2014). Research Design Qualitative Quantitative and Mixed Methods Approaches (J. W. Creswell (ed.); Fourth Edi). SAGE Publication.

Creswell, J. W., \& Poth, C. N. (2018). Qualitative Inquiry \& Research Design: Choosing Among Five Approaches. SAGE Publication.

Dahliyana, A. (2017). Penguatan Pendidikan Karakter Melalui Kegiatan Ekstrakurikuler Di Sekolah. Sosio Religi: Jurnal Kajian Pendidikan Umum, 15(1).

Dianti, P. (2014). I . Jurnal Pendidikan Ilmu Sosial, 23(1). https:// doi.org/https:// doi.org/10.17509/jpis.v23i1.2062

Effendy, M. (2017). Agenda Reformasi Sekolah: Penguatan Pendidikan Karakter. "Penerapan Full Day School Dalam Multi Perspektif (Manajemen, Karakter, Religi, Kultural, Dan Sosial).

Fajrussalam, H., Mansyur, A. S., \& Zaqiah, Q. Y. (2020). Gaining Education Character Based on Cultural Sundanese Values: The Innovation of Islamic Education Curriculum in Facing Era Society 5.0. Jurnal Iqra' : Kajian Ilmu Pendidikan, 5(1), 104119. https:// doi.org/10.25217/ji.v5i1.910

Fischman, W., DiBara, J. A., \& Gardner, H. (2006). Creating good education against the odds. Cambridge Journal of Education, 36(3), 383-398. https:// doi.org/10.1080/03057640600866007

Haryati, S. (2013). Pendidikan karakter dalam kurikulum 2013 Oleh: Sri Haryati (FKIPUTM). Pendidikan Karakter Dalam Kurikulum 2013, 19(2), 259-268.

Husni, H. (2020). Character Education In Indonesia: A Historical Outlook. Educational Review: International Journal, 17(1), 147-162.

Hyland, T., \& Merrill, B. (2003). The changing face of further education: Lifelong learning, inclusion and community values in further education. In The Changing Face of Further Education: Lifelong Learning, Inclusion and Community Values in Further Education. https:/ / doi.org/10.4324/9780203464441 
The Development of Education Character Policy and Programs in Information Society of Kampung Cyber Yogyakarta

Irwan, A., Hudayana, B., Setiadi, Made K, P., \& Indiyanto, A. (2019). Beyond School Reach: Character Education in Three Schools in Yogyakarta, Indonesia. Journal of Educational and Social Research, 9(3), 145. https:// doi.org/10.2478/jesr-2019-0032

Permendikbud RI No 20 Tahun 2018, Permendikbud Nomor 20 tahun 2018 tentang Penguatan Pendidikan Karakter pada Satuan Pendidikan Formal 8 (2018).

Lewis, D., \& Allan, B. (2005). Virtual Learning Communities: A Guide for Practitioners Virtual Learning Communities. 224.

Lickona, T. (1999). Character Education: Seven Crucial Issues. Action in Teacher Education, 20(4), 77-84. https://doi.org/10.1080/01626620.1999.10462937

Miles, M. B., \& Hubberman, A. M. (1994). Qualitative Data Analysis: A Soucebook Of New Methods. (2nd edition) (Second). SAGE Publication.

Noor, T. (2018). Rumusan Tujuan Pendidikan Nasional Pasal 3 Undang-Undang Sisitem Pendidikan Nasional No 20 Tahun 2003. Wahana Karya Ilmiah, 3(01), 123144. Google Scholar

Perpres no. 87 Tahun 2017, 6 September 2017 (2017). https://setkab.go.id/inilahmateri-perpres-no-87-tahun-2017-tentang-penguatan-pendidikan-karakter/

Porawouw, R. (2016). Peran Tokoh Masyarakat dalam Meningkatkan Partisipasi Pembangunan. Politico: Jurnal Ilmu Politik, 3(1), 1154. Google Scholar

Purwanti, D. (2017). Pendidikan Karakter Peduli Lingkungan Dan Implementasinya. DWIJA CENDEKIA: Jurnal Riset Pedagogik, 1(2), 14-20. https:// doi.org/10.20961/jdc.v1i2.17622

Rachman, M., Masrukhi, M., Munandar, A., \& Suhardiyanto, A. (2017). Pengembangan Model Manajemen Pelatihan Dan Pengembangan Pendidikan Karakter Berlokus Padepokan Karakter. Refleksi Edukatika: Jurnal Ilmiah Kependidikan, 8(1). https:// doi.org/10.24176/re.v8i1.1779

Rozafi, V. P. (2019). Studi kasus penguatan pendidikan karakter berbasis budaya sekolah di SD Brawijaya Smart School Malang [Universitas Negeri Malang].Google Scholar

Suhendi, A. (2013). The role of local community leaders in social welfare development. Sosio Informa: Kajian Permasalahan Sosial Dan Usaha Kesejahteraan Sosial, 18(2). https:// doi.org/10.33007/inf.v18i2.73

Towaf, S. M. (2014). Pendidikan Karakter Pada Matapelajaran Ilmu Pengetahuan Sosial. Jurnal Ilmu Pendidikan, 20(1), 75-85. Google Scholar

Tremblay, J. (2019). Kampoeng Cyber: Community-Based Internet Development In PostSuharto Indonesia. University of Toronto.

Umami, I. (2018). Moderating influence of curriculum, pedagogy, and assessment practices on learning outcomes in Indonesian secondary education. Journal of Social Studies Education Research, 9(1), 60-75. https:/ / doi.org/10.17499/jsser.37505

Yama, D., \& General, D. (2015). the Revitalization Policy of Character-Education in. International Journal of Education, 8, 103-113.

Copyright Holder :

(C) Amirrudin, et al., (2021).

First Publication Right :

(C) Jurnal Iqra' : Kajian Ilmu Pendidikan

This article is under:

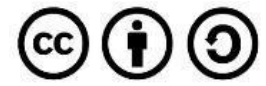

